\title{
ANALISIS PENGEMBANGAN PASAR DURIAN DI KABUPATEN PASURUAN
}

\author{
Analysis Of Durian Market Development In Pasuruan District \\ Muh. Aniar Hari Swasono ${ }^{1,}$ Rr Sri Karuniari Nuswardhani ${ }^{1}$ \\ ${ }^{1}$ Fakultas Pertanian, Universitas Yudharta Pasuruan
}

\begin{abstract}
ABSTRAK
Tujuan dari penelitian ini adalah untuk mengidentifikasi faktor internal (kekuatan dan kelemahan) dan faktor eksternal (peluang dan ancaman) pengembangan pasar durian di daerah penelitian.Analisa yang digunakan dalam penelitian ini adalah analisa SWOT. Dari hasil penelitian didapatkan Faktor-Faktor Internal yang memiliki tingkat kepentingan dari yang tertinggi sampai tingkat terendah terdiri dari: Faktor Kekuatan, potensi sumber daya alam yang dimiliki, Durian masak di pohon, Panen tetap banyak walaupun perawatan tidak intensif, Memiliki warna daging kuning, rasa yang manis dengan aroma harum dan daging yang tebal, Pelayanan ke konsumen yang sudah baik. Faktor Kelemahan, Belum adanya promosi yang lebih intensif, Menggunakan kios seadanya, Harga lebih mahal dari pada durian yang dijual di seberang jalan raya, Kualitas SDM yang masih rendah, Tidak ada kelompok yang menaungi petani durian. Sedangkan faktor-faktor eksternal yang memiliki tingkat kepentingan dari yang tertinggi sampai tingkat terendah terdiri dari: Faktor Peluang, Minat konsumen yang masih tinggi, Daerah pemasaran durian yang masih luas, Adanya pelanggan setia, Adanya keinginan pemerintah untuk memajukan durian kucur. Faktor Ancaman, Perubahan cuaca yang tidak menentu, Adanya pesaing baru, Maraknya impor durian, Kurangnya pemerintah dalam mengembangkan durian lokal, Tidak ada pendampingan dalam berkebun durian. Strategi yang patut di gunakan di dalam Peluang Usaha Agribisnis Buah Durian Di Desa Sumber Rejo Kecamatan Purwosari Kabupaten Pasuruan adalah strategi S-O (Kekuatan-Peluang).
\end{abstract}

Kata kunci : Durian, Kabupaten Pasuruan, Analisis SWOT

\section{ABSTRACT}

The purpose of this study was to identify internal factors (strengths and weaknesses) and external factors (opportunities and threats) to develop the durian market in the study area. The analysis used in this study was a SWOT analysis. From the results of the study obtained Internal Factors that have a level of importance from the highest to the lowest level consisting of: Strength Factors, natural resource potential possessed, ripe durian in the tree, harvest is still plenty even though the treatment is not intensive, has a yellow flesh color, taste sweet with fragrant aroma and thick meat, good service to consumers. Weaknesses, There is no more intensive promotion, Using makeshift kiosks, Prices are more expensive than durian sold across the highway, Quality of human resources is still low, There is no group that houses durian farmers. While external factors that have the highest level of importance from the lowest level consist of: Opportunity Factors, consumer interest is still high, the area of marketing durian is still extensive, the existence of loyal customers, the government's desire to advance durian kucur. Threat Factors, Erratic weather changes, New competitors, Increased durian imports, Lack of government in developing local durians, No assistance in durian gardening. The strategy that should be used in the Durian Fruit Agribusiness 
Business Opportunity in Sumber Rejo Village, Purwosari District, Pasuruan Regency is an S-O (Strength-Opportunity) strategy.

Keywords: Durian, Pasuruan Regency, SWOT Analysis

\section{PENDAHULUAN}

\section{Latar Belakang}

Durian memiliki prospek ekonomi yang cukup bagus disamping buah-buah lainnya. Pemasaran durian selalu meningkat setiap tahunnya menandakan bahwa durian semakin digemari oleh masyarakat, terutama di kota-kota besar di Indonesia. Peluang pasar durian di Indonesia masih menjanjikan, karena permintaan masyarakat terhadap buah ini masih begitu tinggi sehingga harga durian berkualitas dapat mencapi Rp 30.000/kg. Sementara untuk durian dengan kualitas biasa mencapai Rp 15.000/buah. Konsumsi durian di Indonesia pada tahun 2013 hanya sebesar $20 \mathrm{~kg}$. Sedangkan impor durian Indonesia pada tahun 2013 mencapai $4.881 .265 \mathrm{~kg}$. Berdasarkan hasil proyeksi penawaran dan permintaan durian, di Indonesia tahun 2014-2018 terjadi surplus. Pada tahun 2014 surplus durian diperkirakan sebesar 75.993 ton, sementara pada tahun 2019 mengalami penurunan menjadi 71.920 ton. Berdasarkan hasil proyeksi tersebut, sebenarnya Indonesia tidak perlu melakukan impor durian dari negara lain. Hal ini bertolak belakang dengan besarnya impor durian, terutama dari Negara Thailand.

Buah durian merupakan salah satu komoditas unggulan yang ada di Kabupaten Pasuruan. Varietas durian yang ada di Kabupaten Pasuruan adalah Durian lokal, Durian Petruk dan Durian Montong. Potensi luasan tanaman durian yang ada sampai dengan tahun 2012 mencapai 619.385 pohon yang tersebar di beberapa Kecamatan antara lain, Kecamatan Tutur, Purwodadi, Purwosari, Lumbang, Pasrepan dan Puspo dengan penghasil durian terbanyak ada di Kecamatan Puspo dan Pasrepan. Jenis durian lokal merupakan tanaman yang dominan pada beberapa sentra penghasil durian diantaranya Durian Jliteng (spesifik Lumbang), Emas dan Daler (Spesifik Pucangsari), Klawu, Kunir dan lain-lain. Sedangkan durian varietas introduksi yang dikembangkan di Pasuruan adalah Durian Montong dengan luasan mencapai 6 ha tersebar di Kecamatan Tutur, Pasrepan dan Purwodadi (Dinas Pertanian Tanaman Pangan Kabupaten Pasuruan, 2013).

Walaupun Kabupaten Pasuruan menyumbang hasil produksi durian terbesar di Provinsi Jawa Timur, tetapi 
dalam hal pemasaran masih kalah dengan durian dari Luar Jawa atau dari Kabupaten Malang yang lebih dikenal di pasaran. Hal ini dikarenakan pemasarannya masih skala lokal saja. Oleh karena itu, pada bulan Maret 2015 lalu Kabupaten Pasuruan mengadakan festival Cipta Menu Kudapan "Durian Kakap" atau Durian Khas Kabupaten Pasuruan. Adanya festival ini diharapkan masyarakat dari luar kota Pasuruan dapat mengenal Durian yang dihasilkan dari Kabupaten Pasuruan yang nantinya akan berdampak terhadap peningkatan optimalisasi pertanian khususnya komoditas buah durian serta pemasaran produk tersebut baik dalam bentuk buah segar maupun olahan, menyusul komoditas mangga yang sudah terkenal terlebih dahulu bahkan pemasarannya sudah skala ekspor. Selain itu pada tahun 2014 lalu Kabupaten Pasuruan pernah mengadakan kontes durian di Kecamatan Pasrepan dan kontes tersebut dimenangkan oleh "Si Karim", durian ini dikenal dengan warna kuning keemasan serta memiliki ukuran yang besar dan daging yang tebal.

Oleh karena itu, untuk mewujudkan peningkatan pengembangan pasar durian di Kabupaten Pasuruan, maka penelitian mengenai "Potensi Pengembangan Pasar Durian di
Kabupaten Pasuruan" sangat diperlukan dan diharapkan dapat membantu kebijakan pemerintah daerah terkait dengan pengembangan komoditas unggulan tersebut.

\section{Perumusan Masalah}

Berdasarkan uraian latar belakang di atas, perumusan masalah dalam penelitian ini adalah apa saja yang menjadi faktor internal (kekuatan dan kelemahan) dan faktor eksternal (peluang dan ancaman) dalam potensi pemasarandurian di daerah penelitian.

\section{Tujuan Penelitian}

Tujuan dari penelitian ini adalah untuk

1. Mengidentifikasi faktor internal (kekuatan dan kelemahan) dan faktor eksternal (peluang dan ancaman) pemasarandurian di daerah penelitian.

2. Mengetahui faktor-faktor strategis dan menentukan prioritas strategis yang dapat diterapkan untuk mengembangkan potensi pasar durian.

\section{Kegunaan Program}

Penelitian yang telah dilakukan diharapkan dapat memberikan kegunaan:

a. Bagi peneliti, sebagai sumber informasi ilmiah dan acuan untuk penelitian yang lebih lanjut dan lebih mendalam.. 
b. Bagi masyarakat, dapat dan tidak adanya pemasok yang dapat memberikan informasi dan diandalkan. Peluang (opportunities) pengetahuan mengenai potensi merupakan situasi yang menguntungkan pasar buah durian di Kabupaten dalam lingkungan suatu perusahaan. Pasuruan.

c. Bagi pemerintah, sebagai bahan identifikasi atas segmen pasar yang pertimbangan dalam mengambil kebijakan mengenai pengembangan pasar buah durian sebagai komoditas unggulan di Kabupaten Pasuruan.

\section{TINJAUAN PUSTAKA}

\section{Analisis SWOT}

Menurut Pearce dan Robinson (2011, p. 200), analisis SWOT merupakan salah satu teknik yang digunakan untuk menciptakan gambaran yang bersifat umum, secara tepat mengenai situasi strategis suatu perusahaan. Kesesuaian yang baik pada sumber daya internal perusahaan (kekuatan dan kelemahan) dengan situasi eksternal (peluang dan ancaman) dijadikan suatu asumsi yang mendasar dalam analisis SWOT ini. Menurut Bateman dan Snell (2008, p. 170), Kekuatan (strength) organisasi mencakup manajemen yang profesional, arus kas yang positif, merek yang terkemuka dan telah dikenal secara luas. Kelemahan (weakness) mencakup sebelumnya sempat terlewatkan, perubahan kondisi persaingan atau regulasi, perubahan teknologi, dan membaiknya suatu hubungan dengan pembeli atau pemasok, dapat digunakan sebagai peluang oleh perusahaan. Ancaman (threats) termasuk didalamnya adalah pesaing baru, pertumbuhan pasar yang lamban, meningkatnya kekuatan tawar-menawar pembeli dan pemasok, perubahan teknologi dan direvisinya suatu peraturan akan dapat menjadi ancaman bagi keberhasilan suatu perusahaan.

Untuk memudahkan dalam melaksanakan analisis SWOT diperlukan matriks SWOT. Empat jenis strategi dalam SWOT (David, 2010):

1. Strategi SO (SO Strategies), strategi yang memanfaatkan kekuatan internal perusahaan untuk menarik suatu keuntungan atas peluang eksternal.

2. Strategi WO (WO Strategies), strategi yang bertujuan untuk memperbaiki kelemahan internal dengan cara mengambil keuntungan dari peluang eksternal.

kurangnya kapasitas produksi cadangan 
3. Strategi ST (ST Strategies), strategi yang memanfaatkan kekuatan yang dimiliki oleh sebuah perusahaan untuk menghindari atau mengurangi dampak ancaman eksternal.

4. Strategi WT (WT Strategies), merupakan taktik untuk bertahan yang diarahkan dalam mengurangi kelemahan internal serta menghindari ancaman eksternal.

\section{METODE PENELITIAN}

\section{Rancangan Penelitian}

Penelitian ini dilaksanakan di Desa Sumber Rejo Dusun Kucur Kecamatan Purwosari Kabupaten Pasuruan. Pemilihan lokasi penelitian dilakukan secara purposive (sengaja) dengan pertimbangan bahwa Desa Sumber Rejo termasuk penghasil durian terbesar di Kabupaten Pasuruan selain di Desa Ngembal dan Lumbang. Penelitian dilaksanakan selama delapan bulan. Metode penelitian yang digunakan adalah metode kualitatif dengan metode survei menggunakan wawancara dan observasi. Penarikan informan dilakukan dengan purposive sampling, responden yang digunakan yaitu petani dan pedagang durian yang berada di Desa Sumber Rejo Dusun Kucur Kabupaten Pasuruan.
Penelitian ini menggunakan dua macam data yaitu, data primer dan sekunder. Data primer didapatkan dari hasil wawancara dengan responden menggunakan metode in-depth interview atau secara mendalam berdasarkan daftar pertanyaan (kuesioner) yang telah disiapkan. Sedangkan data sekunder digunakan untuk memperoleh gambaran umum penelitian yang didapatkan melalui berbagai sumber, yaitu Biro Pusat Statistik Kabupaten Pasuruan, website pemerintah daerah, Kantor Desa dan Kecamatan yang ada di Kabupaten Pasuruan dan instansiinstansi lain yang berkaitan dengan penelitian ini.

\section{Teknik Analisis Data}

Analisa yang digunakan dalam penelitian ini adalah analisa SWOT untuk menentukan "Potensi Pengembangan Pasar Durin Kabupaten Pasuruan”. SWOT adalah singkatan dari kekuatan (Strengths) dan kelemahan (Weaknesses) merupakan faktor internal serta peluang (Opportunities) dan ancaman (Threats) merupakan faktor ekternal. Analisis SWOT membandingkan antara faktor internal dan faktor ekternal dengan asumsi bahwa suatu strategi yang efektif dan memaksimalkan kekuatan dan peluang serta meminimalkan kelemahan dan ancaman. 
Indikator faktor internal yang pedagang pengumpul atau tengkulak mempengaruhi potensi pengembangan sebanyak 10 orang dan pedagang ecer pasar durian mencakup berbagai variabel sebanyak 10 orang dan kebanyakan yang terkait dengan aspek di antaranya: berperan ganda sebagai petani durian juga. kelembagaan, produksi, sumber daya fisik dan sumber daya finansial. Sedangkan indikator faktor ekternal terdiri dari variabel yang terkait dengan beberapa aspek di antaranya: Kebijakan pemerintah, kondisi pasar input/output, kondisi sosial masyarakat, kondisi perekonomian, perkembangan sektor swasta, kondisi politik dan keamanan serta hama/penyakit serta perubahan kondisi alam atau perubahan cuaca.

\section{HASIL DAN PEMBAHASAN}

Penelitian ini dilakukan di Desa Sumber Rejo Dusun Kucur Kecamatan Purwosari Kabupaten Pasuruan dengan sampel penelitian petani, pedagang pengumpul dan pedagang pengecer. Sampel dalam penelitian ini dibatasi 10 petani dengan lahan diatas 1 hektar. Hal ini dikarenakan hampir sebagian besar penduduk di Dusun Kucur yang berjumlah $\pm 500 \mathrm{KK}$ mempunyai tanaman durian, ada yang berjumlah 2 pohon ataupun 3 pohon dan kebanyakan berada di pekarangan dengan bermacam-macam tanaman misalnya ada tanaman kopi, nangka dan alpukat. Sedangkan untuk

\section{Faktor-Faktor Internal}

Banyak faktor - faktor yang mempengaruhi Strategi Pemasaran Buah Durian di Desa Sumber Rejo Dusun Kucur Kecamatan Purwosari Kabupaten Pasuruan, diantaranya faktor internal dan faktor eksternal. Faktor internal yaitu faktor - faktor yang berasal dari dalam atau tempat penelitian. Faktor - Faktor Internal tersebut terdiri dari Kekuatan(S), Kelemahan(W) :

\section{Faktor Kekuatan(S)}

Kekuatan (Strengths) adalah sumber daya dan keterampilan yang memberikan keunggulan, keuntungan pada tempat penelitian. Adapun faktor yang mempengaruhi di antaranya :

\section{a. Potensi Sumber Daya Alam yang Dimiliki}

Buah durian merupakan salah satu komoditi unggulan Kabupaten Pasuruan. Beberapa wilayah di Kabupaten Pasuruan menjadi sentra produksi buah Durian ini, tercatat produksi buah durian di Kabupaten Pasuruan mencapai $\pm 13.970,08$ ton/ 
tahundengan luas lahan produksi sebesar 899,96 ha. Salah satunya adalah tanaman durian yang berada di Kecamatan Purwosari Desa Sumber Rejo Dusun Kucur. Hampir sebagian besar masyarakat di Dusun ini mengusahakan tanahnya untuk budidaya tanaman durian. Hal ini didukung keadaan geografis yang memang sesuai dengan budidaya tanaman durian baik dilihat dari jenis tanah, keadaan topografi maupun curah hujan. Kondisi lahan yang subur juga membuat tanaman durian bisa tumbuh baik di Desa Sumber Rejo Dusun Kucur. Oleh karena itu, berdagang durian merupakan usaha yang potensial yang ada di Desa Sumber Rejo khususnya Dusun Kucur ini.

\section{b. Durian Masak di Pohon}

Durian di Desa Sumber Rejo Dusun Kucur ini berbeda rasanya jika dibandingkan dengan durian dari daerah lainnya yang ada di Kabupaten Pasuruan. Hal ini dikarenakan, durian di panen bukan dalam keadaan masih belum matang kemudian diperam, tetapi memang sudah matang atau masak pohon. Durian yang masak di pohon memiliki rasa yang manis legit dan juga beraroma sangat wangi, berbeda dari durian yang belum masak namun sudah di panen yang rasa dan aromanya sudah memudar. Rata-rata bahkan keseluruhan petani durian yang ada di Dusun Kucur menunggu durian masak di atas pohon, sehingga memiliki rasa sangat lezat dan aroma yang lebih kuat.

\section{c. Memiliki Warna Daging Kuning, Rasa yang Manis dengan Aroma Harum dan Daging yang Tebal}

Kualitas merupakan salah satu hal utama yang dipertimbangkan oleh seorang konsumen dalam membeli suatu produk. Durian yang ada di Dusun Kucur ini mempunyai kualitas yang sesuai dengan permintaan pasar. Durian Kucur memiliki rasa yang manis mirip seperti Durian montong, warna daging buah kuning dan tebal serta aroma yang harum. Hal tersebut membuat kualitas Durian Kucur bisa dikategorikan unggul dan disejajarkan dengan durian lokal yang ada di Kabupaten Pasuruan seperti di Desa Ngembal atau Desa Lumbang yang selama ini sudah lebih dikenal oleh masyarakat. 


\section{d. Panen Tetap Banyak Walaupun} Perawatan tidak Intensif

Tanaman durian yang ada di dusun Kucur sebagian besar sudah berumur 40 tahun lebih hal ini dikarenakan tanaman durian yang diusahakan memang kebanyakan berasal dari warisan sebelumnya. Walaupun sebagian besar sudah berumur tua, tetapi tidak ada pemeliharaan atau perawatan khusus untuk tanaman durian. Dilihat dari segi perawatan, petani juga jarang sekali merawat tanaman durian yang ada,kebanyakan hanya dibiarkan saja. Tetapi ada sebagian kecil yang merawat tanaman durian mereka dan itu hanya sebatas memberikan pupuk yang hanya dilakukan dua kali dalam setahun, yaitu ketika sudah panen dan sebelum musim hujan. Walaupun tidak ada perlakukan khusus atau perawatan, tetapi tanaman durian yang ada di dusun Kucur tetap berbuah sepanjang tahunnya. Bahkan ada beberapa tanaman yang panen hingga dua kali dalam setahun.

\section{e. Pelayanan ke Konsumen yang Sudah Baik}

Pelayanan merupakan hal yang sangat penting dalam berdagang. Hal ini dikarenakan, konsumen adalah "Raja". Adanya jaminan pembelian produk yang tidak sesuai dengan keinginan konsumen sudah diterapkan oleh semua pedagang durian yang ada di Dusun Kucur ini. Hal ini terbukti dari adanya komplain yang ditanggapi secara langsung oleh pedagang apabila ada konsumen yang membeli durian tidak sesuai dengan yang diharapkan. Jadi, pedagang langsung mengganti buah durian tersebut sampai keinginan konsumen terpenuhi.

\section{Faktor Kelemahan(W).}

Kelemahan (weaknesses) adalah keterbatasan atau kekurangan dalam sumber daya dan keterampilan yang secara serius menghambat kinerja suatu usaha yang akan di jalankan. Adapun faktor yang mempengaruhi diantaranya adalah sebagai berikut :

\section{a. Harga lebih Mahal dari Durian Lokal lainnya}

Karena memiliki kualitas yang lebih bagus, durian lokal yang ada di Dusun Kucur ini harganya jauh lebih mahal dibandingkan dengan durian yang ada di sekitar daerah Pasuruan sendiri. Pada dasarnya produk yang 
memiliki kualitas bagus, selalu diikuti dengan harga yang tinggi pula.

Harga durian berkisar antara $\mathrm{Rp}$ 30.000 hingga Rp 100.000. Harga durian sendiri bukan tergantung dari besar atau kecilnya ukuran, tetapi didasarkan atas kualitas dari durian sendiri. Jadi ada durian dengan ukuran kecil yang mempunyai harga mahal, karena kualitasnya memang bagus.

\section{b. Belum Adanya Promosi yang Lebih Intensif}

Promosi Durian di Dusun Kucur selama ini hanya dilakukan melalui media dari mulut ke mulut. Kebanyakan para pedagang belum memanfaatkan kemajuan teknologi yang ada untuk mempromosikan produk mereka. Hal ini dikarenakan, keterbatasan kemampuan maupun pengetahuan mereka dalam mengakses teknologi tersebut. Pedagang sendiri juga beranggapan bahwa tanpa media promosi yang lain, sudah bisa di pastikan durian mereka pasti laku. Hal inilah yang meyebabkan mereka enggan dan tetap mempertahankan metode promosi yang ada. Meskipun metode ini mempunyai keuntungan karena pedagang terbantu oleh konsumen tetap dalam mempromosikan Durian di Dusun Kucur. Namun demikian, perlu upaya yang lebih baik dalam meningkatkan jangkauan promosi sehingga Durian Kucur ini dapat dikenal oleh masyarakat yang lebih luas lagi.

\section{c. Menggunakan Kios Seadanya}

Pedagang durian di Dusun Kucur ini masih menggunakan sarana dan prasarana yang sederhana. Bahkan banyak yang belum mempunyai kios khusus untuk menjual buah durian sendiri. Jadi selama ini kebanyakan pedagang menjual durian di halaman depan rumah mereka masing-masing. Hal ini sangat berpengaruh pada konsumen yang ingin menikmati durian secara langsung di tempat, karena tempat tidak nyaman.

\section{d. Kualitas SDM yang Masih Rendah}

Kualitas SDM ini berkaitan dengan perkembangan teknik budidaya durian yang dilakukan. Kebanyakan petani durian di Dusun Kucur ini tidak terlalu memperhatikan atau mengembangkan teknik budidaya durian sendiri, asalkan bisa 
berbuah tiap musimnya saja mereka sudah puas. Kemungkinan bila petani bisa selalu mengembangkan dan terus berinovasi, hasil durian yang didapatkan akan jauh lebih besar lagi dan pasokan yang ada bisa kontinyu tiap musimnya.

\section{e. Tidak ada Kelompok Petani}

Kelompok tani merupakan tempat dimana para petani bisa belajar, bermutifasi dan memperoleh tambahan ilmu pengetahuan, perkembangan teknologi khususnya di bidang pertanian. Melalui kelompok tani para anggota bisa menyerap beberapa informasi ataupun tukar pikiran sesama anggota kelompok tani dan juga sebagai tempat bermusyawarah antar sesama anggota apabila terdapat suatu permasalahan di dalam kelompok tani. Walaupun sebagian besar penduduk di Dusun Kucur adalah petani durian, sayangnya belum ada wadah atau kelompok petani yang menaungi petani durian tersebut. Hal ini menyebabkan permasalahan yang ada hanya bisa diatas oleh petani itu sendiri.
Faktor Eksternal adalah suatu faktor yang datangnya dari luar lingkungan petani. Adapun faktor yang mempengaruhi terdiri dari peluang (O) dan $\operatorname{ancaman}(\mathrm{T})$.

\section{Faktor Peluang (O)}

Peluang (Opportunities) adalah situasi penting yang menguntungkan di dalam suatu usaha. Terdiri dari beberapa faktor diantaranya :

\section{a. Adanya Keinginan pemerintah untuk Memajukan Durian Kucur}

Adanya beberapa event yang sudah dilakukan pemerintah daerah, misalnya saja makan durian gratis sangat membantu sekali untuk memperkenalkan durian lokal yang ada di Dusun Kucur ini. Walaupun banyak juga durian lokal dari daerah lain yang mengikuti event ini juga. Tetapi, ini bisa dijadikan sebagai ajang untuk mencari informasi durian mana yang paling banyak di minati konsumen, sehingga mendorong petani untuk meningkatkan kualitas produk buah durian mereka.

\section{b. Minat Konsumen yang Sangat Tinggi}

Faktor - Faktor Eksternal. 
Bagi penggemar durian, harga dan tempat tidak menjadi masalah karena mereka akan rela datang jauhjauh ke tempat tujuan hanya untuk membeli durian. Khususnya bagi konsumen yang menyukai durian lokal karena durian lokal memiliki rasa yang berbeda dengan durian impor. Hendaknya minat konsumen terhadap durian lokal ini harus dapat dimanfaatkan sebaik mungkin oleh pedagang Durian di Dusun Kucur untuk bisa menjualkan produknya.

\section{c. Daerah Pemasaran Durian yang} Masih Luas

Selama ini pemasaran durian di Dusun Kucur masih berada di area Pasuruan dan Mojokerto saja. Hal ini dikarenakan promosi yang masih sangat terbatas menyebabkan jangkauan pemasaran masih terbatas di dua kota ini saja. Mungkin dengan adanya pendampingan bagi pedagang untuk mengenalkan produknya melalui internet, pemasaran durian di Dusun Kucur bisa lebih luas lagi dan dapat dikenal oleh masyarakat umum di daerah lain.

\section{d. Adanya Pelanggan Setia}

Setiap produk yang mempunyai kualitas yang bagus dan terjamin tentunya akan mempunyai pelanggan setia. Sama halnya dengan pembeli durian di Dusun Kucur ini karena sudah tahu kualitas dari produk yang dihasilkan, maka sudah mempunyai beberapa pelanggan setia yang selalu datang bila musim sudah tiba. Pelanggan setia ini ada yang berasal dari daerah Pasuruan maupun luar Pasuruan. Tetapi pelanggan setia masih di dominasi oleh konsumen yang berada di daerah Pasuruan. Adanya pelanggan setia sendiri membawa keuntungan sekali bagi pedagang durian untuk memasarkan produknya. Biasanya pelanggan setia ini kebanyakan akan menceritakan kepada teman, keluarga ataupun orang lain tentang kualitas produk durian di Dusun Kucur ini. Memang pemasaran yang paling efektif dan tidak memerlukan biaya adalah dengan pemasaran dari mulut ke mulut ini, dikarenakan orang jauh lebih percaya kepada orang yang sudah pernah mencoba atau membuktikan kulitas dari durian di Dusun Kucur tersebut. 
Ancaman adalah situasi penting yang tidak menguntungkan dalam lingkungan suatu perusahaan atau tempat penelitian. Terdiri dari :

\section{a. Tidak Ada Pendampingan dalam}

\section{Berkebun Durian}

Selama ini tidak ada program khusus dari pemerintah daerah atau dinas terkait mengenai pendampingan dalam teknik budidaya durian. Jadi selama ini petani durian hanya memelihara kebun durian seadanya saja, asalkan berbuah sudah cukup. Mereka tidak mengetahui teknik bagaimana agar buah durian yang dihasilkan bisa meningkat dari tahun ke tahunnya. Oleh karena itu, peran pemerintah daerah atau dinas terkait untuk mengembangkan durian lokal yang ada di Dusun Kucur ini sangat dibutuhkan.

\section{b. Kurangnya Perhatian Pemerintah} dalam Mengembangkan Durian

\section{Lokal}

Buah durian merupakan salah satu produk unggulan yang ada di Pasuruan. Tetapi perhatian atau pembinaan kepada petani durian khususnya di Dusun Kucur ini masih sangat terbatas sekali. Durian di
Dusun Kucur ini padahal memiliki potensi atau prospek yang bagus untuk dikembangkan, apalagi hampir semua penduduk yang ada di Dusun ini mempunyai lahan durian. Selama ini, perhatian pemerintah daerah dalam mengembangkan buah durian masih belum merata di seluruh Kabupaten Pasuruan. Perhatian pemerintah daerah masih terpusat di Kecamatan Pasrepan, hal ini dikarenakan pemenang kontes durian terbaik ada di Kecamatan Pasrepan. Seharusnya kalau memang pemerintah daerah menginginkan durian sebagai produk unggulan, pendampingan khusus kepada petani hendaknya bisa dilakukan secara menyeluruh ke daerah-daerah potensial penghasil buah durian.

\section{c. Adanya Pesaing Baru}

Hampir semua produk selalu ada pesaing, baik itu yang berada di dalam daerah maupun dari luar daerah. Di Pasuruan sendiri pesaing dari durian yang ada di Dusun Kucur ini berada di Kecamatan Purwodadi, Kecamatan Tutur, Kecamatan Puspo, Kecamatan Lumbang, Kecamatan Pasrepan, Kecamatan Prigen dan kecamatan Sukorejo. Apalagi pesaing 
dari luar daerah jauh lebih banyak lagi, bahkan durian import juga menjadi pesaing yang tidak bisa dianggap remeh. Oleh karena itu, untuk tetap mempertahankan durian yang ada di Dusun Kucur agar bisa bersaing, image produk dan kualitas produk harus tetap dipertahankan. Pelayanan yang baik kepada konsumen-pun merupakan hal utama yang harus tetap dijaga.

\section{d. Maraknya Durian Impor}

Masuknya durian impor, apalagi di supermarket-supermarket besar memberikan efek dan sangat mempengaruhi perkembangan durian lokal khususnya durian yang ada di Dusun Kucur sendiri. Konsumen yang enggan datang jauh-jauh ke Dusun Kucur jauh akan memilih membeli durian di supermarket. Apalagi gaya hidup masyarakat saat ini yang lebih praktis dan tidak mau membuang waktu lebih memilih membeli di supermarket. Hal tersebut bisa mengencam keberadaan durian lokal sendiri, khususnya durian yang ada di Dusun Kucur.

\section{e. Perubahan Cuaca yang tidak Menentu}

Faktor cuaca sangat menentukan produksi dari buah durian sendiri. Musim hujan sepanjang tahun membuat Durian tidak berbuah. Cuaca yang tidak menentu ini apabila tidak disikapi dengan baik maka akan merugikan pedagang sendiri, karena produksi durian mereka akan terus menurun. Perlu adanya perawatan yang intensif dan perlakuan-perlakuan tertentu di kala cuaca yang tidak menentu seperti sekarang ini. Sebenarnya buah durian masih tetap akan bisa berbuah asalkan mendapatkan perawatan secara intensif maupun dengan perlakuanperlakuan tertentu. Adanya penemuan inovasi baru yang dapat mencegah kerontokan bunga pada saat cuaca tidak menentu dirasakan sangat membantu sekali bagi petani buah durian.

\section{Tahap Masukan (Input Stage)}

Tahap masukan terdiri dari matriks IFE (Internal Faktor Evaluation) dan EFE (Eksternal Faktor Evaluation). Tahap ini merupakan tahap awal dalam merumuskan strategi setelah mengidentifikasi faktor faktor internal dan eksternal.

Matriks IE (Internal-Eksternal Matrix) 
Setelah melakukan identifikasi Berdasarkan identifikasi terhadap faktorterhadap faktor-faktor internal, faktor strategis internal, yaitu kekuatan selanjutnya dibuat matrik IFE yang (strengths) dan kelemahan (weaknesses) meliputi kekuatan dan kelemahan dari diperoleh hasil pembobotan dan peringkat potensi pengembangan pemasaran durian. sebagai berikut:

Tabel 1. Matriks IFE (Internal Faktor Evaluation) Pemasaran Durian Kucur

\begin{tabular}{|c|c|c|c|c|}
\hline \multicolumn{5}{|c|}{ FAKTOR STRATEGI INTERNAL } \\
\hline \multicolumn{2}{|c|}{ Strength (Kekuatan) } & Bobot & Peringkat & Skor \\
\hline S1 & Potensi SDA yang dimiliki & 0,157 & 3,7 & $\mathbf{0 , 5 8 0}$ \\
\hline $\mathbf{S 2}$ & Durian masak di pohon & 0,152 & 3,2 & 0,486 \\
\hline $\mathbf{S 3}$ & $\begin{array}{l}\text { Memiliki warna daging kuning, rasa yang } \\
\text { manis dengan aroma harum dan daging } \\
\text { yang tebal }\end{array}$ & 0,081 & 3,5 & 0,283 \\
\hline S4 & $\begin{array}{l}\text { Panen tetap banyak walaupun perawatan } \\
\text { tidak intensif }\end{array}$ & 0,086 & 3,6 & 0,31 \\
\hline S5 & Pelayanan ke konsumen yang sudah baik & 0,076 & 3,1 & 0,236 \\
\hline \multicolumn{5}{|c|}{ FAKTOR STRATEGI INTERNAL } \\
\hline \multicolumn{5}{|c|}{ Weaknesses (Kelemahan) } \\
\hline $\mathbf{W 1}$ & $\begin{array}{l}\text { Harga lebih mahal dari pada durian yang } \\
\text { dijual di seberang jalan raya }\end{array}$ & 0,088 & 2,3 & 0,202 \\
\hline W2 & $\begin{array}{l}\text { Belum adanya promosi yang lebih } \\
\text { intensif }\end{array}$ & 0,144 & 2,8 & 0,403 \\
\hline W3 & Menggunakan kios seadanya & 0,088 & 2,6 & 0,228 \\
\hline W4 & Kualitas SDM yang masih rendah & 0,07 & 2,7 & 0,189 \\
\hline W5 & $\begin{array}{l}\text { Tidak ada kelompok yang menaungi } \\
\text { petani durian }\end{array}$ & 0,058 & 1,9 & 0,110 \\
\hline & Total & 1 & & $\mathbf{3 , 0 2 7}$ \\
\hline
\end{tabular}

Sumber: Data Primer diolah, 2017

Berdasarkan hasil penelitian matriks IFE, faktor strategis yang merupakan kekuatan terbesar dan paling berpengaruh terhadap pemasaran durian adalah Potensi Sumber Daya Alam yang dimiliki dengan nilai tertimbang 0,580 . Hal ini dikarenakan Desa Sumber Rejo Dusun Kucur ini termasuk dataran tinggi dengan suhu udara yang dingin sangat tepat sekali untuk pengembangan tanaman durian.
Apalagi sebagian besar tanaman durian yang ada di Dusun kucur ini sudah ada sejak puluhan tahun lamanya. Faktor strategi internal yang merupakan kelemahan terbesar dalam pemasaran durian adalah belum adanya promosi yang lebih intensif dengan nilai tertimbang 0,403. Hal ini di karenakan media promosi masih terbatas dari mulut ke mulut yang biasanya di lakukan oleh 
konsumen yang merasa puas setelah untuk mengatasi kelemahan dengan menikmati durian di Dusun Kucur menggunakan kekuatan tergolong tinggi.

kemudian mereka menceritakan kepada sanak famili dan keluarga mereka. Belum adanya media promosi berbasis teknologi menyebabkan keterbatasan pengenalan durian di Dusun Kucur ini, sehingga kebanyakan konsumen yang datang berasal dari daerah Pasuruan, Surabaya dan Sidoarjo saja.

Hasil analisis matriks IFE untuk kekuatan dan kelemahan diperoleh total nilai tertimbang berada pada rata-rata

\section{Matriks EFE (Eksternal Faktor \\ Evaluation)}

Berdasarkan identifikasi terhadap faktor-faktor strategis eksternal pengembangan pemasaran durian, yaitu dengan memasukkan peluang (opportunities) dan ancaman (threats) kemudian diberi bobot dan peringkat maka diperoleh hasil seperti pada tabel dibawah ini.

yaitu sebesar 3,027 ini menunjukkan

dalam pengembangan pemasaran durian

Tabel 2. Matriks EFE (Eksternal Faktor Evaluation) Pemasaran Durian Kucur

\begin{tabular}{|l|l|l|l|l|}
\hline FAKTOR STRATEGI EKSTERNAL & Bobot & Peringkat & Skor \\
\hline Opportunities (peluang) & $\begin{array}{l}\text { Adanya keinginan pemerintah untuk } \\
\text { memajukan durian kucur }\end{array}$ & 0,1 & 3,4 & 0,34 \\
\hline O1 & Adanya pelanggan setia & 0,167 & 3,7 & $\mathbf{0 , 6 1 8}$ \\
\hline O3 & Minat konsumen yang sangat tinggi & 0,167 & 3,7 & $\mathbf{0 , 6 1 8}$ \\
\hline O4 & $\begin{array}{l}\text { Daerah pemasaran durian yang masih } \\
\text { luas }\end{array}$ & 0,106 & 3,4 & 0,36 \\
\hline FAKTOR STRATEGI EKSTERNAL & \begin{tabular}{l}
$\mid$ \\
\hline Threats (Ancaman) \\
\hline T1
\end{tabular} $\begin{array}{l}\text { Tidak ada pendamping dalam berkebun } \\
\text { durian }\end{array}$ & 0,061 & 2,3 & 0,14 \\
\hline T2 & $\begin{array}{l}\text { Kurangnya perhatian pemerintah dalam } \\
\text { mengembangkan durian lokal }\end{array}$ & 0,07 & 2,5 & 0,175 \\
\hline T3 & Adanya pesaing & 0,085 & 3 & 0,255 \\
\hline T4 & Maraknya impor durian & 0,077 & 2,7 & 0,208 \\
\hline T7 & Perubahan cuaca yang tidak menentu & 0,167 & 3,7 & $\mathbf{0 , 6 1 8}$ \\
\hline Total & $\mathbf{1}$ & & $\mathbf{3 , 3 3 2}$ \\
\hline
\end{tabular}

Sumber: Data Primer diolah, 2017

Berdasarkan hasil perhitungan berpengaruh terhadap pemasaran durian matriks EFE, faktor strategis yang adalah minat konsumen yang sangat tinggi merupakan peluang terbesar dan paling dan adanya pelanggan setia dengan nilai 
tertimbang 0,618. Hal ini menunjukkan minat konsumen akan Durian Kucur sangat tinggi, ini bisa terlihat dari banyaknya pengunjung setiap akhir pekan yaitu hari Sabtu dan Minggu, walaupun konsumen masih sebatas dari tiga daerah saja, yaitu Pasuruan, Surabaya dan Sidoarjo. Selain itu juga ada pelanggan setia Durian Kucur yang loyal dan setiap musim durian selalu datang ke Dusun Kucur.

Faktor eksternal yang menjadi ancaman dalam pemasaran durian adalah perubahan cuaca yang tidak menentu, ini dapat dilihat dari nilai tertimbangnya yaitu sebesar 0,618. Hal ini terbukti dimana pada tahun 2016, cuaca sangat ekstrim melanda hampir seluruh Indonesia termasuk di Pasuruan. Sepanjang tahun 2016 daerah Pasuruan di landa hujan berkepanjangan. Hal ini menjadikan bunga tanaman durian menjadi rontok sehingga gagal menjadi buah dan pada tahun 2016 kemarin sangat banyak durian yang rusak serta gagal panen.

Hasil analisis matriks EFE untuk peluang dan ancaman diperoleh total nilai tertimbang sebesar 3,332. Hal ini menunjukkan bahwa dalam pengembangan pemasaran durian untuk merespons peluang dan ancaman tergolong tinggi.

\section{Tahap Pencocokan (Matvhing Stage)}

Tahap pencocokan merupakan tahap dalam proses perumusan strategi, berfungsi untuk memadukan kekuatan dan kelemahan dengan peluang dan ancaman dari lingkungan eksternal. Alat analisis yang digunakan adalah Matriks IE (Internal-Ekaternal) dan Matriks SWOT (Strengths-Weaknesses-Opportunities-

Threats), untuk menghasilkan alternatif strategi untuk pengembangan pasar durian di Kabupaten Pasuruan.

\section{Matriks IE (Internal-Eksternal Matrix)}

Kegunaan dari matrik IE adalah untuk mengetahui posisi pengembangan pasar durian untuk saat ini. Pemetaan posisi pemasaran durian sangat penting dalam pemilihan strategi yang diterapkan. Berdasarkan hasil analisis yang telah dilakukan sebelumnya, total nilai tertimbang pada matrik IFE adalah 3,027 yang artinya faktor internal tergolong tinggi, sedangkan nilai tertimbang pada matriks EFE adalah 3,332 yang artinya dalam faktor eksternal juga tergolong tinggi.

Apabila masing-masing total nilai tertimbang dari IFE dan EFE dipetakan dalam matriks IE, maka posisi pemasaran durian saat ini berada pada kotak kuadran I yang menggambarkan bahwa 
pengembangan pasar durian dalam kondisi kembang (Growth dan Build). Strategi internal tinggi dan dalam kondisi eksternal terbaik yang cocok adalah strategi intensif juga tergolong tinggi. Inti strategi yang (penetrasi pasar, pengembangan pasar, diterapkan dalam pengembangan pasar dan pengembangan produk). durian adalah strategi tumbuh dan

Total nilai IFE yang diberi bobot

$$
\begin{array}{ccc}
\text { Kuat } & \text { Rata-rata } & \text { Lemah } \\
3,0-4,0 & 2,0-2,99 & 1,0-1,99
\end{array}
$$

Tinggi

$3,0-4,0$

Menengah

$2,0-3,99$

Rendah

$1,0-1,99$

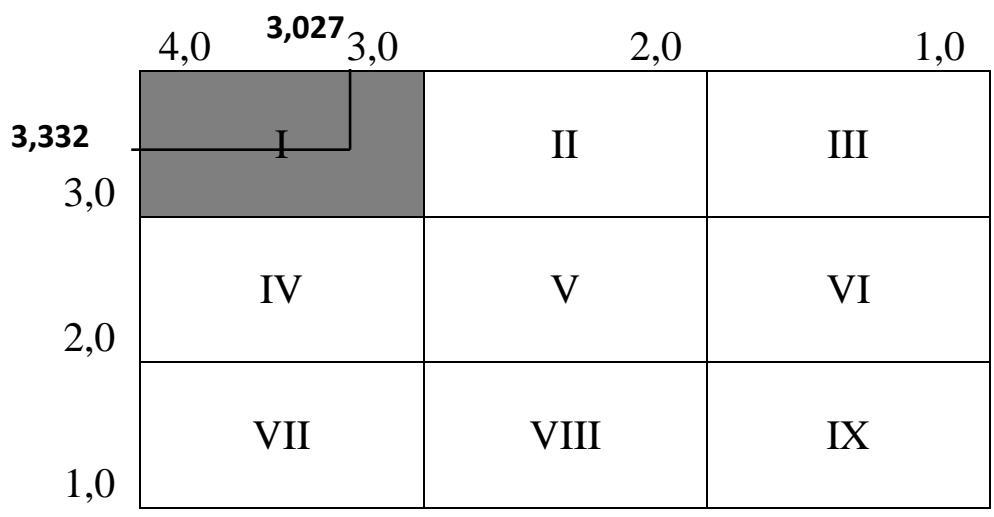

Matrik SWOT (Strengths-Weaknesses- disarankan yaitu strategi SO (kekutan-

Opportunities-Threats Matrix)

Tujuan dari tahap pencocokan (matriks SWOT) adalah untuk menghasilkan alternatif strategi yang layak, bukan untuk memilih strategi yang terbaik. Empat tipe strategi yang peluang/strength-opportunities), strategi WO (kelemahan-peluang/weaknessesopportuities), strategi ST (kekuatanancaman/strength-threats), dan strategi WT (kelamahan-ancaman/weaknessesthreats). 
Tabel 3. Matriks SWOT

\begin{tabular}{|c|c|c|}
\hline Faktor Internal & $\begin{array}{l}\text { Kekuatan (Strength-S) } \\
\text { 1. Potensi SDA yang dimiliki } \\
\text { 2. Durian masak dipohon } \\
\text { 3. Memiliki Warna daging } \\
\text { rasa kuning, rasa yang } \\
\text { manis dengan aroma harum } \\
\text { dan daging yang tebal } \\
\text { 4. Panen tetap banyak } \\
\text { walaupun perawatan tidak } \\
\text { intensif kif konsumen } \\
\text { 5. Pelayanan ke } \\
\text { yang sudah baik }\end{array}$ & $\begin{array}{l}\text { Kelemahan (Weaknesses- } \\
\text { W) } \\
\text { 1. Harga lebih mahal dari } \\
\text { pada durian yang dijual } \\
\text { di seberang jalan raya } \\
\text { 2. Belum adanya promosi } \\
\text { yang lebih intensif } \\
\text { 3. Menggunakan } \\
\text { seadanya kios } \\
\text { 4. Kualitas SDM yang } \\
\text { masih rendah } \\
\text { 5. Tidak ada kelompok } \\
\text { yang menaungi petani } \\
\text { durian }\end{array}$ \\
\hline $\begin{array}{l}\text { Peluang } \\
\text { (Opportunities-O) } \\
\text { 1. Adanya keinginan } \\
\text { pemerintah untuk } \\
\text { memajukan durian kucur } \\
\text { 2. Adanya pelanggan setia } \\
\text { 3. Minat konsumen yang } \\
\text { masih tinggi } \\
\text { 4. Daerah pemasaran } \\
\text { durian yang masih luas }\end{array}$ & $\begin{array}{l}\text { Strategi S-O } \\
\text {-Menginformasikan kelebihan- } \\
\text { kelebihan yang dimiliki durian } \\
\text { kucur (S1,S2,S3,S4) } \\
\text {-Optimalisasi penggunaan } \\
\text { berbagai media untuk media } \\
\text { promosi } \\
\text { (S2,S3,S4,S5,O1,O2,O4) } \\
\text {-Mempertahankan pelayanan } \\
\text { meningkatkan jan perta } \\
\text { terhadap konsumen jaringan } \\
\text { memperbaiki pemasaran } \\
\text { distribusi dan } \\
(\mathrm{S} 2, \mathrm{~S} 3, \mathrm{~S} 4, \mathrm{~S} 5, \mathrm{O} 1, \mathrm{O} 2, \mathrm{O} 3, \mathrm{O} 4,)\end{array}$ & $\begin{array}{l}\text { Strategi W-O } \\
\text {-Menjaga kepercayaan } \\
\text { konsumen dengan kualitas } \\
\text { produk (W1,W2,O2,O4) }\end{array}$ \\
\hline $\begin{array}{l}\text { Ancaman (Threat-T) } \\
\text { 1. Tidak ada pendampingan } \\
\text { dalam berkebun durian } \\
\text { 2. Kurangnya pemerintah } \\
\text { dalam mengembangkan } \\
\text { durian lokal } \\
\text { 3. Adanya pesaing baru } \\
\text { 4. Maraknya impor durian } \\
\text { 5. Perubahan cuaca yang } \\
\text { tidak menentu }\end{array}$ & $\begin{array}{l}\text { Strategi S-T } \\
\text {-Menjalin kemitraan dengan } \\
\text { pemerintah dan lembaga } \\
\text { keuangan }(\mathrm{S} 1, \mathrm{O} 1, \mathrm{O} 2, \mathrm{O} 3, \mathrm{O} 4)\end{array}$ & $\begin{array}{l}\text { Strategi W-T } \\
\text {-Perbaikan kios pedagang } \\
\text { durian }(\mathrm{W} 3, \mathrm{~T} 2, \mathrm{~T} 3)\end{array}$ \\
\hline
\end{tabular}




\section{Strategi S-O (Strengths-Weaknesses)}

Strategi S-O (StrengthsWeaknesses) atau strategi kekuatanpeluang merupakan strategi yang menggunakan kekuatan internal untuk memanfaatkan peluang eksternal. Strategi yang dapat digunakan dalam pengembangan pasar durian yaitu menginformasikan kelebihan-kelebihan yang dimiliki durian Kucur. Dengan menginformasikan kelebihan-kelebihan yang di miliki oleh durian di Dusun Kucur diharapkan akan meningkatkan banyaknya konsumen yang datang dan berkunjung untuk menikmati durian lokal di Desa Kucur. Strategi ini juga didukung dengan beberapa kelebihan diantaranya adalah, durian sudah masak dipohon, daging buah memiliki warna kuning dan tebal, rasa yang manis dengan aroma harum.

Terdapat strategi lain yang juga dapat diterapkan dalam pengembangan pasar durian yaitu optimalisasi penggunaan berbagai media untuk promosi. Di tengah zaman modern sekarang ini penggunaan media sosial sangatlah penting, pemanfaatan media sosial seperti facebook instagram BBM dan WA sangat ampuh di gunakan sebagai media promosi sebab banyak sekali penggunanya serta tidak membutuhkan biaya yang terlalu besar sebagai media informasi. Adanya promosi di berbagai media sosial diharapkan dapat menarik konsumen dan mengenalkan durian di Dusun Kucur sendiri.

Mempertahankan dan meningkatkan pelayanan terhadap konsumen serta memperbaiki jaringan distribusi dan pemasaran. Pelayanan pada konsumen merupakan hal yang sangat penting dikarenakan pembeli adalah raja yang harus di layani dengan baik. Selain pelayanan pentingnya jaringan distribusi juga hal yang harus di perhatikan agar saluran pemasaran dari petani kepada konsumen tidak terlalu melewati tangan yang banyak sehingga akan menaikkan harga durian di tingkat petani.

\section{Strategi W-O (Weaknesses-} Opportunities)

Strategi W-O (WeaknessesOpportunities) atau strategi kelemahanpeluang merupakan stategi untuk meminimalkan kelemahan yang ada untuk memanfaatkan peluang eksternal. Strategi yang dapat di gunakan dalam pemasaran durian yaitu menjaga kepercayaan konsumen dengan kualitas produk. Ratarata penjual durian di Dusun Kucur menjual produknya kepada konsumen dengan menjamin kualitas di mana jika 
ada durian yang tidak memuaskan seperti, rasa yang tidak manis atau duriannya busuk maka akan di ganti oleh penjual durian dengan cuma-cuma tanpa mengganti uang.

\section{Strategi S-T (Strength-Threats)}

Strategi S-T (Strength-Threats) atau strategi kekuatan-kelemahan merupakan strategi untuk meminimalkan kelemahaan yang ada untuk memanfaatkan peluang eksternal. Strategi yang dapat digunakan dalam pengembangan pasar durian yaitu menjalin kemitraan dengan pemerintah serta lembaga keuangan. Terjalinnya kemitraan dengan pemerintah merupakan kunci bagi pedagang durian untuk mengembangkan usahanya. Pemerintah sendiri dapat menjadi jembatan antar pedagang serta lembaga keuangan yang selama ini belum terjalin. Diharapkan dengan adanya kerjasama antara pedagang dengan lembaga keuangan, pedagang bisa mendapatkan pinjaman untuk tambahan modal dalam mengembangkan usahanya. Selain itu, Pemerintah dapat melakukan pendampingan kepada pedagang durian dalam mengembangkan usahanya yaitu dengan bantuan pemerintah dalam menggunakan perkembangan teknologi informasi yang ada sebagai media promosi durian lokal di Dusun Kucur sendiri. Promosi yang dapat digunakan bisa dalam bentuk media cetak maupun elektronik, seperti iklan di televisi maupun di internet. Pemerintah juga dapat membantu pedagang durian dalam diversifikasi produk olahan buah durian, yang nantinya dapat meningkatkan nilai tambah dari produk durian sendiri

\section{Strategi W-T (Weaknesses-Threats)}

\section{Strategi W-T (Weaknesses-}

Threats) atau strategi kelemahan-ancaman merupakan strategi meminimalkan kelemahan yang ada serta menghindari ancaman. Strategi yang dapat digunakan dalam pengembanagan pasar durian yaitu dengan perbaikan kios para pedagang.

Salah satu faktor yang mempengaruhi minat konsumen dalam membeli suatu produk adalah faktor kenyamanan tempat. Kios-kios yang didirikan oleh pedagang durian masih terbatas dan kurang menarik perhatian di mata konsumen. Kebanyakan pedagang durian di Dusun Kucur tidak memiliki kios tersendiri untuk menjual produknya. Kios yang digunakan oleh para pedagang biasanya adalah halaman rumah mereka dengan meja kecil dan sederhana untuk menaruh produknya. Dengan adanya perbaikan kios ini diharapkan konsumen dapat menjadi lebih nyaman dalam 
membeli durian. Kenyamanan konsumen adalah faktor utama yang harus terpenuhi dalam mendirikan sebuah kios. Pedagang durian dapat memperbaiki kios yang dimiliki dan membuatnya senyaman dan seindah mungkin sehingga konsumen yang membeli dapat merasa betah ditempat. Masing-masing kios diharapkan mempunyai tempat untuk pembeli yang ingin menyantap durian di tempat.

\section{KESIMPULAN DAN SARAN}

\section{Kesimpulan}

Dari hasil penelitian sebelumnya dapat ditarik beberapa kesimpulan sebagai berikut:

1. Faktor-Faktor Internal yang memiliki tingkat kepentingan dari yang tertinggi sampai tingkat terendah terdiri dari:

a. Faktor Kekuatan, potensi sumber daya alam yang dimiliki, Durian masak di pohon, Panen tetap banyak walaupun perawatan tidak intensif, Memiliki warna daging kuning, rasa yang manis dengan aroma harum dan daging yang tebal, Pelayanan ke konsumen yang sudah baik.

b. Faktor Kelemahan, Belum adanya promosi yang lebih intensif, Menggunakan kios seadanya, Harga lebih mahal dari pada durian yang dijual di seberang jalan raya, Kualitas SDM yang masih rendah, Tidak ada kelompok yang menaungi petani durian.

Sedangkan faktor-faktor eksternal yang memiliki tingkat kepentingan dari yang tertinggi sampai tingkat terendah terdiri dari:

a. Faktor Peluang, Minat konsumen yang masih tinggi, Daerah pemasaran durian yang masih luas, Adanya pelanggan setia, Adanya keinginan pemerintah untuk memajukan durian kucur.

b. Faktor Ancaman, Perubahan cuaca yang tidak menentu, Adanya pesaing baru, Maraknya impor durian, Kurangnya pemerintah dalam mengembangkan durian lokal, Tidak ada pendampingan dalam berkebun durian.

2. Strategi yang patut di gunakan di dalam Peluang Usaha Agribisnis Buah Durian Di Desa Sumber Rejo Dusun Kucur Kecamatan Purwosari Kabupaten Pasuruan adalah strategi S-O (KekuatanPeluang) Strategi ini di buat dengan cara memanfaatkan 
kekuatan untuk merebut dan memanfaatkan peluang yang ada dan menghadapi serta mengatasi ancaman. Strategi yang di gunakan antara lain :

a. Menginformasikan kelebihankelebihan yang dimiliki durian kucur

b. Optimalisasi penggunaan berbagai media untuk media promosi

c. Mempertahankan dan meningkatkan pelayanan terhadap konsumen serta memperbaiki jaringan distribusi dan pemasaran

\section{Saran}

Berdasarkan kesimpulan diatas, maka dapat diajukan saran sebagai berikut:

1. Bagi pemerintah daerah, sebaiknya memberikan fasilitas berupa kebijakan dan bantuan modal untuk mengembangkan potensi pasar durian di dusun Kucur pada khususnya dan di daerah Pasuruan pada umumnya.

2. Bagi Dinas Pertanian, sebaiknya memberikan penyuluhan mengenai teknik dan budidaya tanaman durian yang baik agar bisa diperoleh hasil yang maksimal.

3. Peningkatan ketrampilan melalui diversifikasi produk olahan buah durian sangat diperlukan guna menambah nilai tambah dari buah durian dan untuk meningkatkan pendapatan masyarakat sekitar.

\section{DAFTAR PUSTAKA}

Anonim. 30 Agustus (2013). Saatnya Durian Indonesia Menguasai Dunia.

bibitdurianmontongunggul.blogsp ot.com diakses pada tanggal 5 Oktober 2015.

Arif H. Ayik. 18 April (2012). Inilah Destinasi Durian di Pasuruan. https://ayikngalah.wordpress.com diakses pada tanggal 5 Oktober 2015.

Bateman, Thomas S. \& Snell, Scott A. (2008). Manajemen: Kepemimpinan dan Kolaborasi dalam Dunia yang Kompetitif. (7th ed., Buku. 1). Jakarta: Salemba Empat.

David, Fred R. (2010). Manajemen Strategis: Konsep. (12th ed., Vol. 1). Jakarta: Salemba Empat.

Dinas Pertanian Tanaman Pangan Kabupaten Pasuruan. (2013). Durian. www.dispertakabpasuruan.com diakses pada tanggal 5 Oktober 2015.

Dolly. (2006). Analisis kelayakan investasi pengusahaan durian (Durio zibethinus)CV Milad Perkasa Rancamaya Bogor. [Skripsi]. Bogor: Fakultas Pertanian, Institut Pertanian Bogor.

Monsaputra. (2007). Dayasaing durian di Sumatera Barat (kasus: 
KabupatenPadang Pariaman dan Kabupaten Tanah Datar). [skripsi]. Bogor: FakultasPertanian, Institut Pertanian Bogor.

Pearce, John A. \& Robinson, Richard B. (2011). Manajemen Strategi: Formulasi, Implementasi, dan Pengendalian. Jakarta: Salemba Empat
Pusat Data dan Sistem Informasi Pertanian. 2014. Outlook Komoditi Durian. Sekretariat Jendral Kementrian Pertanian. Jakarta.

Setiadi. 1999. Bertanam Durian. Jakarta: Penebar Swadaya 